\title{
Co-inoculation and inoculation methods of plant growth-promoting bacteria in wheat yield performance
}

\section{Coinoculação e métodos de inoculação de bactérias promotoras de crescimento de plantas no desempenho produtivo da cultura do trigo}

\author{
Luiz Júnior Perini ${ }^{1 *}$; Douglas Mariani Zeffa ${ }^{2}$; William Rafael Roesler ${ }^{3} ;$ Claudemir \\ Zucareli4; Leandro Simões Azeredo Gonçalves ${ }^{4}$
}

\section{Highlights}

Inoculation with $A$. brasilense does not always change wheat grain yield.

Post-emergence inoculation provided higher grain yield.

Post-emergence inoculation can replace nitrogen topdressing fertilization.

\begin{abstract}
Several studies have reported the beneficial effects of inoculation of Azospirillum brasilense in wheat, but only a few of them have related the co-inoculation of $A$. brasilense and Rhizobium sp. and the evaluation of different inoculation methods. This study aimed $i$ ) to verify the efficiency of plant growth-promoting bacteria (PGPB) in subtropical environments, ii) to verify the efficiency of co-inoculation of $A$. brasilense and Rhizobium sp., and iii) to verify the efficiency of the management of different inoculation methods in the wheat crop. The experiments were carried out in Londrina and Apucarana, State of Paraná, Brazil, under a complete randomized block design, with four replications and nine treatments: T1) absence of nitrogen (N) topdressing, T2) $30 \mathrm{~kg} \mathrm{ha}^{-1}$ of $\mathrm{N}$ topdressing, T3) $60 \mathrm{~kg} \mathrm{ha}^{-1}$ of $\mathrm{N}$ topdressing, T4) A. brasilense Ab-V5 in the seeds, T5) $A$. brasilense Ab-V5 in post-emergence, T6) $A$. brasilense Ab-V5 + Rhizobium sp. 53GRM1 in the seeds, T7) $A$. brasilense Ab-V5 + Rhizobium sp. 53GRM1 in post-emergence, T8) commercial inoculant ( $A$. brasilense $\mathrm{Ab}-\mathrm{V} 5+\mathrm{Ab}-\mathrm{V} 6)$ in the seeds, and T9) commercial inoculant (A. brasilense $\mathrm{Ab}-\mathrm{V} 5+\mathrm{Ab}-\mathrm{V} 6)$ in postemergence. The number of ears per linear meter, number of spikelets, number of grains per spikelet, number of grains per ear, thousand-grain weight, number of spikelets to ears ratio, leaf nitrogen content, and grain

1 Discente do Curso de Doutorado do Programa de Pós-Graduação em Agronomia, Departamento de Agronomia, Universidade Estadual de Londrina, UEL, Londrina, PR, Brasil. E-mail: luiz.j.perini@outlook.com

2 Discente do Curso de Doutorado do Programa de Pós-Graduação em Genética e Melhoramento de Plantas, Departamento de Agronomia, Universidade Estadual de Maringá, UEM, Maringá, PR, Brasil. E-mail: douglas.mz@ hotmail.com

3 Discente do Curso de Engenharia Agronômica, Departamento de Agronomia, UEL, Londrina, PR, Brasil. E-mail: willian_ roesler@hotmail.com

${ }^{4}$ Profs. Drs., Programa de Pós-Graduação em Agronomia, Departamento de Agronomia, UEL, Londrina, PR, Brasil. E-mail: claudemircca@uel.br; leandrosag@uel.br

* Author for correspondence
\end{abstract}

Received: Nov. 21, 2019 - Approved: Nov. 17, 2020 
yield were evaluated. Leaf $\mathrm{N}$ content and yield components showed no alterations due to the inoculation and co-inoculation performed both in the seed and in the post-emergence of seedlings. Treatments T3, T7, and T9 showed the highest means of grain yield (2077.50, 1743.12, and $1660.62 \mathrm{~kg} \mathrm{ha}^{-1}$, respectively), demonstrating that co-inoculation with $A$. brasilense Ab-V5 + Rhizobium sp. 53GRM1 and inoculation with $A$. brasilense $\mathrm{Ab}-\mathrm{V} 5+\mathrm{Ab}-\mathrm{V} 6$, both in post-emergence of seedlings, have the potential to replace the topdressing nitrogen fertilization in wheat.

Key words: Azospirillum brasilense. Nitrogen. Rhizobium sp. Triticum aestivum.

\section{Resumo}

Em trigo, embora diversos estudos já tenham sido relatados sobre os efeitos benéficos da inoculação de Azospirillum brasilense, são escassos na literatura trabalhos relacionados ao uso de coinoculação de A. brasilense e Rhizobium sp., bem como a avaliação de diferentes métodos de inoculação. Os objetivos do estudo foram: $\boldsymbol{l}$ ) verificar a eficiência de bactérias promotoras do crescimento de plantas (BPCP) em ambientes subtropicais; ii) verificar a eficiência da coinoculação de $A$. brasilense e Rhizobium sp.; e iii) verificar a eficiência do manejo de diferentes métodos de inoculação na cultura do trigo. Os experimentos foram conduzidos nos municípios de Londrina e Apucarana, Paraná, sob o delineamento experimental de blocos completos ao acaso, com quatro repetições e nove tratamentos: T1) ausência de nitrogênio (N) em cobertura; T2) $30 \mathrm{~kg} \mathrm{ha}^{-1}$ de N em cobertura; T3) $60 \mathrm{~kg} \mathrm{ha}^{-1}$ de N em cobertura; T4) A. brasilense Ab-V5 nas sementes; T5) $A$. brasilense Ab-V5 em pós-emergência; T6) $A$. brasilense Ab-V5 + Rhizobium sp. 53 GRM1 nas sementes; T7) A. brasilense Ab-V5 + Rhizobium sp. 53GRM1 em pós-emergência; T8) Inoculante comercial (A. brasilense Ab-V5 + Ab-V6) nas sementes; e T9) Inoculante comercial (A. brasilense Ab-V5 + Ab-V6) em pós-emergência. Foram avaliadas as seguintes características: número de espigas por metro linear, número de espiguetas, número de grãos por espigueta, número de grãos por espiga, massa de mil grãos, relação número de espiguetas e espigas, teor de nitrogênio nas folhas e produtividade de grãos. $\mathrm{O}$ teor de $\mathrm{N}$ foliar e os componentes do rendimento não foram alterados pela inoculação e coinoculação realizada tanto na semente quanto em pós-emergência das plântulas. Os tratamentos T3, T7 e T9 apresentaram as maiores médias de produtividade de grãos (2077,50; 1743,12 e 1660,62 $\mathrm{kg} \mathrm{ha}^{-1}$, respectivamente), demonstrando que a coinoculação com $A$. brasilense Ab-V5 + Rhizobium sp. 53GRM1, bem como a inoculação com $A$. brasilense Ab-V5 + Ab-V6, ambos em pós-emergência das plântulas, apresentam potencial para substituir a adubação nitrogenada de cobertura na cultura do trigo.

Palavras-chave: Azospirillum brasilense. Nitrogênio. Rhizobium sp. Triticum aestivum.

\section{Introduction}

Wheat (Triticum aestivum) is one of the most important cereals for human consumption worldwide and locally. Brazil has a deficit of approximately $60 \%$ between production and consumption (Companhia Nacional de Abastecimento [CONAB],
2020), making it dependent on imports from countries such as Argentina, Canada, and the United States. Among the main obstacles to the development of wheat cultivation in Brazil are the lack of public policies, adverse climate conditions, high production costs, and low profitability (Galindo et al., 2018). Chemical fertilizers, especially nitrogen fertilizers, 
represent a high cost in production, reaching up to $30 \%$ of the total costs (CONAB, 2020). In addition, the indiscriminate use of nitrogen fertilizers has caused serious environmental problems, including water eutrophication, soil acidification, and air pollution (Chen et al., 2018).

Nitrogen $(\mathrm{N})$ is considered the most absorbed and exported nutrient by the wheat plant, which is why its deficiency constitutes a limiting factor and directly influences the number of tillers, number of ears, spikelet development, grain weight, and, consequently, grain yield (Vaghar \& Ehsanzadeh, 2018; UIAllah et al., 2018). According to Ladha et al. (2016), the two main strategies to reduce the dependence on nitrogen fertilizers in wheat cultivation is by increasing its use efficiency by plants and the use of diazotrophic bacteria. These bacteria can supply nitrogen to plants through non-symbiotic nitrogen fixation. Also, these microorganisms can favor nutrient uptake by plants, acting as biofertilizers, phytostimulators, and mitigators of abiotic and biotic stresses (Lugtenberg \& Kamilova, 2009; Pii et al., 2015; Zeffa et al., 2018).

The genus Azospirillum spp. has been widely studied in the wheat crop (Piccinin et al., 2013; Fukami, Nogueira, Araujo, \& Hungria, 2016; Di Salvo, Ferrando, Fernández-Scavino, \& Salamone, 2018; Galindo et al., 2020), and it is the constituent of commercial biofertilizers. Veresoglou and Menexes (2010) found that inoculation with Azospirillum spp. in wheat crop increased grain yield by $8.9 \%$ in a meta-analysis study based on 59 scientific articles. However, an increase of $14 \%$ in yield was observed when considering only the experiments with no topdressing nitrogen fertilization. In Brazil, inoculants containing the elite strains of Azospirillum brasilense
(Ab-V5 and Ab-V6) have been exponentially employed by farmers in recent years, mainly in corn, wheat, sugarcane, and brachiaria crops, in addition to being used as co-inoculants in soybean and bean (Hungria, Araujo, Silva, Barbosa, \& Zilli, 2017; Zeffa et al., 2019, 2020).

Several studies have shown the benefits of co-inoculation of bacteria of the genera Azospirillum and Rhizobium in the wheat crop (Kavimandan, 1985; Galal, ElGhandour, \& El-Akel, 2001; Yanni et al., 2016). In general, bacteria of the genus Rhizobium are used as inoculants in legume crops, as there is a symbiotic association between the plant and the bacterium, leading to the formation of nodules in the roots (Ohyama, 2017). The benefits of Rhizobium for legume plants are mainly due to the $\mathrm{N}$ supply through the biological $\mathrm{N}_{2}$ fixation (BNF) process (Hoang, Tóth, \& Stacey, 2020). Bacteria of the genus Rhizobium can be associated with the rhizosphere of wheat plants, characterizing external colonization and promoting benefits through the production and release of auxins, gibberellins, siderophores, phosphorus solubilization, and biocontrol of several root diseases (Patil, Kale, Ajane, Sheikh, \& Patil, 2017).

Standard inoculation with $A$. brasilense inwheat, recommendedbymostmanufacturers, is performed by mixing the inoculant with the seeds in pre-sowing. However, seed treatment with fungicides can provide toxicity to nontarget microorganisms and influence the efficiency of Azospirillum spp. and other plant growth-promoting bacteria (PGPB) (Yang, Hamel, Vujanovic, \& Gan, 2011). Thus, postemergence inoculation can be considered a viable alternative to circumvent this problem (Fukami et al., 2016). 
Although several studies have already reported the beneficial effects of inoculation of $A$. brasilense in wheat, few of them have related the co-inoculation of $A$. brasilense and Rhizobium sp. and the evaluation of different inoculation methods. Thus, this study aimed I) to verify the efficiency of plant growth-promoting bacteria (PGPB) in subtropical environments, ii) to verify the efficiency of co-inoculation of $A$. brasilense and Rhizobium sp., and iii) to verify the efficiency of the management of different inoculation methods in the wheat crop.

\section{Material and Methods}

\section{Experimental conditions}

The experiments were conducted in the experimental area of the State University

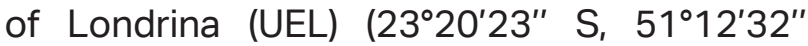
W, $532 \mathrm{~m}$ altitude) and the farm Estância Natureza, located in Apucarana (2331'17"
S and $51^{\circ} 27^{\prime} 10^{\prime \prime} \mathrm{W}, 790 \mathrm{~m}$ altitude), during the 2016 agricultural year. The soil in the UEL experimental area is classified as eutrophic Red Latosol, while the soil on the farm Estância Natureza is classified as eutrophic Red Nitosol. Both municipalities are in the State of Paraná, Brazil, and the climate is classified as Cfa, i.e., a subtropical humid mesothermal climate, according to Köppen classification. The data of precipitation and maximum and minimum temperatures were obtained from the Agronomic Institute of Paraná (IAPAR) for Londrina and the Meteorological System of Paraná (SIMEPAR) for Apucarana (Figure 1). Soil chemical analyses $(0-20 \mathrm{~cm})$ were carried out before the experiments were set up, presenting the following results in Londrina and Apucarana, respectively: $\mathrm{pH}\left(\mathrm{CaCl}_{2}\right)=4.17$ and 5.24, $\mathrm{P}=7.53$ and $12.97 \mathrm{mg} \mathrm{dm}^{-3}, \mathrm{~K}^{+}=$ 0.22 and $1.15 \mathrm{cmol}_{\mathrm{c}} \mathrm{dm}^{-3}, \mathrm{Ca}^{2+}=3.75$ and 8.95 $\mathrm{cmol}_{\mathrm{c}} \mathrm{dm}^{-3}, \mathrm{Mg}^{2+}=0.65$ and $2.04 \mathrm{cmol}_{\mathrm{c}} \mathrm{dm}^{-3}$, effective CEC $=4.62$ and $12.14 \mathrm{cmol}_{\mathrm{c}} \mathrm{dm}^{-3}$, and $\mathrm{V} \%=38.53$ and 70.99.

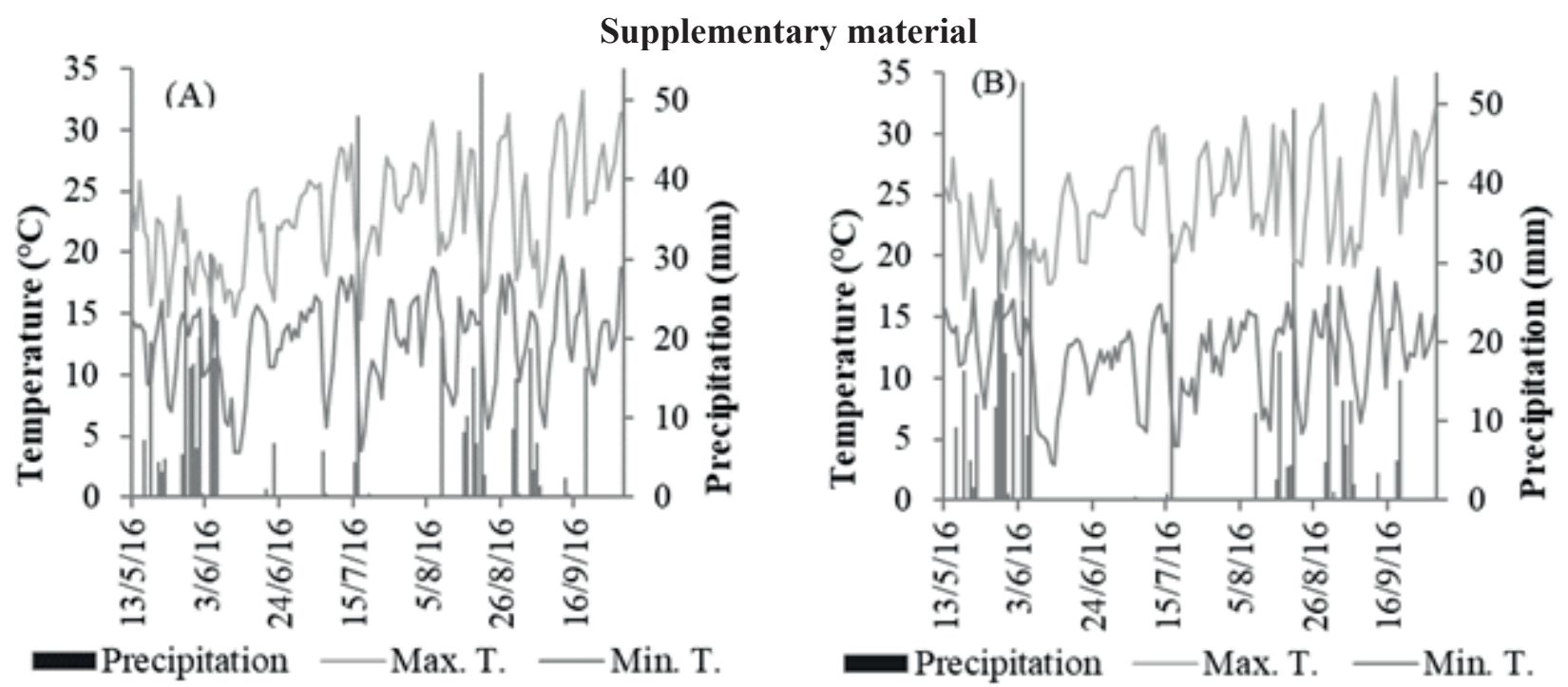

Figure 1. Daily data of precipitation and maximum and minimum temperature during the experimental period in Londrina (A) and Apucarana (B) in the 2016 agricultural year. 
The experimental design was complete randomized blocks, with four replications and nine treatments: T1) absence of nitrogen (N) topdressing, T2) $30 \mathrm{~kg} \mathrm{ha}^{-1}$ of $\mathrm{N}$ topdressing, T3) $60 \mathrm{~kg} \mathrm{ha}^{-1}$ of $\mathrm{N}$ topdressing, T4) $A$. brasilense Ab-V5 in the seeds, T5) $A$. brasilense Ab-V5 in post-emergence, T6) $A$. brasilense Ab-V5 + Rhizobium sp. 53GRM1 in the seeds, T7) $A$. brasilense $\mathrm{Ab}-\mathrm{V} 5+$ Rhizobium sp. 53GRM1 in post-emergence, T8) commercial inoculant ( $A$. brasilense $A b$ $\mathrm{V} 5+\mathrm{Ab}-\mathrm{V} 6)$ in the seeds, and T9) commercial inoculant $(A$. brasilense Ab-V5 + Ab-V6) in post-emergence.

The plots consisted of 28 rows $5 \mathrm{~m}$ long, with an inter-row spacing of $0.17 \mathrm{~m}$ and a density of 441 seeds $\mathrm{m}^{-2}$. The useful area of the plots was defined as the 26 central rows without the $0.5 \mathrm{~m}$ from each end, which corresponded to $17.68 \mathrm{~m}^{2}$. The wheat cultivar used in the experiments was $C D$ 150 (Coodetec), which has a small size, early cycle, high production potential in soils with good fertility, good sanity, and blast tolerance, being used as flour-improving wheat in the food industry. The fungicide pyraclostrobin and the insecticides thiophanate-methyl and fipronil were used for seed treatment at a dose of $2 \mathrm{~mL} \mathrm{~kg}-1$ of seeds. Seed treatment was carried out five days before sowing, while seed inoculation with PGPB was carried out during sowing. Sowing was carried out on May 13, 2016, in Londrina and May 23, 2016. in Apucarana. Sowing fertilization consisted of $200 \mathrm{~kg} \mathrm{ha}^{-1}$ of the NPK formulation 10-15-15, considering the soil chemical analyses and crop recommendations (Silva, Bassoi, \& Foloni, 2017)

\section{Bacterial growth and inoculation}

The bacteria used in the noncommercial inoculant are deposited in the collection of bacterial cultures of the Laboratory of Molecular Biochemistry of UEL (LBM-UEL). Colonies of Ab-V5 and Rhizobium sp. 53GRM1 were grown as pre-inoculum in liquid DYGS medium ( $2 \mathrm{~g}$ of glucose, $1.5 \mathrm{~g}$ of peptone, $2 \mathrm{~g}$ of yeast extract, $0.5 \mathrm{~g}$ of $\mathrm{K}_{2} \mathrm{HPO}_{4^{\prime}}$ $0.5 \mathrm{~g}$ of $\mathrm{MgSO}_{4^{\prime}}$ and distilled water q.s. to $1 \mathrm{~L}$, $\mathrm{pH}$ 6.0) for 24 hours. Then, they were multiplied in $250 \mathrm{~mL}$ of liquid M15 medium (Oliveira et al., 2017) and cultured for 48 hours under stirring in an orbital incubator $\left(180 \mathrm{rpm}\right.$ at $\left.28^{\circ} \mathrm{C}\right)$. After this period, the cultures were interrupted and the cell concentration was determined by counting in a Neubauer chamber, with subsequent standardization of the cell suspension and dilution to a concentration of $1 \times 10^{8}$ bacterial cells $\mathrm{mL}^{-1}$ of the inoculant.

The inoculants were applied at a concentration of $1 \times 10^{8}$ bacterial cells $\mathrm{mL}^{-1}$ for treatments T4 and T6 using $30 \mathrm{~mL}$ of inoculant per $\mathrm{kg}$ of seed. Seed inoculation for treatment T8 was performed using the commercial product Qualyfix $(A$. brasilense strains Ab$\mathrm{V} 5+\mathrm{Ab}-\mathrm{V} 6)$ using $6 \mathrm{~mL}$ of inoculant per $\mathrm{kg}$ of seed at a commercial concentration of $5 \times$ $10^{8}$ bacterial cells $\mathrm{mL}^{-1}$. Treatments with postemergence inoculation (T5 and T7) received 2.5 $\mathrm{L} \mathrm{ha}^{-1}$ of inoculants at a concentration of $1 \times 10^{8}$ bacterial cells $\mathrm{mL}^{-1}$ using a knapsack sprayer at seven days after seedling emergence. The treatment commercial inoculant in postemergence (T9) received $500 \mathrm{~mL} \mathrm{ha}^{-1}$ of the Qualyfix inoculant at a concentration of $5 \times$ $10^{8}$ bacterial cells $\mathrm{mL}^{-1}$. Treatments T2 and T3 received 30 and $60 \mathrm{~kg} \mathrm{ha}^{-1}$ of $\mathrm{N}$ topdressing, respectively, at the beginning of tillering, with ammonium sulfate as the $\mathrm{N}$ source. 
Agronomic characteristics and nitrogen content

The following characteristics were evaluated: grain yield (GY, in $\left.\mathrm{kg} \mathrm{ha}^{-1}\right)$, corrected to $13 \%$ moisture; thousand-grain weight (TGW, in $\mathrm{g}$ ), according to the rules for seed testing; number of ears per linear meter (NEM); number of grains per ear (NGE); number of grains per spikelet (NGS); number of spikelets to ears ratio (SER); and leaf nitrogen content (LNC, in $\mathrm{g}$ $\left.\mathrm{kg}^{-1}\right)$. LNC was determined using 30 flag leaves collected from each plot, packed in paper bags, and taken to a forced-air ventilation oven at $65{ }^{\circ} \mathrm{C}$ until constant mass. Subsequently, the samples were ground, homogenized and aliquots of $0.1 \mathrm{~g}$ were taken for later $\mathrm{N}$ determination using the Kjeldahl method through digestion, distillation, and titration processes, as described by Bremner and Mulvaney (1982).

\section{Data analysis}

The dataweresubjected to theindividual analysis of variance and, subsequently, to joint analysis of variance after detecting the homogeneity of residual variances by the Bartlett (1937) test. The means were grouped by the Scott and Knott (1974) clustering test at a 5\% probability level when there was statistical significance $(P<0.05)$. Statistical analyses were performed using the software R (http://www.rproject.org), using the easyanova package (Arnhold, 2013).

\section{Results and Discussion}

Most of the agronomic characteristics showed a significant effect of environment, except for SER and LNC. On the other hand, only GY presented a significant effect of treatment. Only the characteristic LNC had a significant effect $(P<0.05)$ for the interaction treatments $\times$ environments (Table 1 ), indicating a differential behavior of treatments relative to environmental variations. Although Londrina and Apucarana showed similar variations in temperature and precipitation (Figure 1), a high difference was observed regarding the soil fertility of these environments. According to Castro-Sowinski, Herschkovitz, Okon and Jurkevitch (2007), the response to inoculation may vary according to the environmental conditions, soil chemical, physical, and/or biological characteristics, plant genotype, bacterial strain, and quality of PGPB cells used as inoculants. 
Table 1

Summary of the joint analysis of variance and coefficient of variation (CV) of seven agronomic characteristics evaluated in the wheat cultivar CD 150 as a function of different forms of fertilization in experiments conducted in Londrina and Apucarana in the 2016 agricultural year

\begin{tabular}{|ccccccccc|}
\hline \multirow{2}{*}{ SV } & DF & \multicolumn{7}{c|}{ Mean square $^{1}$} \\
\cline { 3 - 8 } & & NEM & SER & NGS & NGE & TGW & GY & LNC \\
\hline Block/Site & 6 & 148.73 & 1.71 & 0.059 & 43.10 & 2.22 & 1814.88 & 13.90 \\
\hline Treatment (T) & 8 & 26.91 & 0.75 & 0.073 & 48.29 & 3.30 & $537.26^{* *}$ & 29.15 \\
\hline Environment (E) & 1 & $1462.50^{*}$ & 2.41 & $2.456^{* *}$ & $279.66^{*}$ & $356.00^{* *}$ & $14113.01^{*}$ & 12.87 \\
\hline T $\times$ E & 8 & 33.56 & 0.74 & 0.022 & 20.10 & 4.66 & 232.07 & $42.35^{*}$ \\
\hline Residual & 48 & 20.08 & 0.92 & 0.099 & 33.43 & 2.38 & 122.91 & 16.69 \\
\hline Apucarana & & 39.90 & 16.16 & 3.31 & 51.64 & 36.57 & 1967.50 & 19.74 \\
\hline Londrina & & 30.88 & 16.52 & 2.94 & 47.70 & 32.12 & 1082.03 & 18.9 \\
\hline Overall mean & & 35.39 & 16.43 & 3.13 & 49.67 & 34.35 & 1524.76 & 19.32 \\
\hline CV (\%) & & 12.65 & 5.86 & 10.05 & 11.64 & 4.49 & 22.96 & 21.14 \\
\hline
\end{tabular}

${ }^{1} \mathrm{GY}=$ grain yield; TGW = thousand-grain weight; NEM: number of ears per linear meter; NGE = number of grains per ear; NGS = number of grains per spikelet; SER = number of spikelets to ears ratio; LNC = leaf nitrogen content.

${ }^{*},{ }^{* *}$ significant at the 5 and $1 \%$ probability level by the F-test, respectively.

The means of GY of the treatments $A$. brasilense Ab-V5 + Rhizobium sp. 53GRM1 in post-emergence (1743.12 $\left.\mathrm{kg} \mathrm{ha}^{-1}\right)$ and commercial inoculant $(A$. brasilense Ab-V5 + $\mathrm{Ab}-\mathrm{V} 6)$ in post-emergence (1660.62 $\mathrm{kg} \mathrm{ha}^{-1}$ ) did not differ statistically from the treatment $60 \mathrm{~kg} \mathrm{ha}^{-1}$ of $\mathrm{N}$ topdressing (2035.43 $\mathrm{kg} \mathrm{ha}^{-1}$ ) by the Scott and Knott test, which were higher than the other treatments (Figure 2). Thus, these treatments could completely replace $\mathrm{N}$ fertilization in the wheat crop. Some studies have observed that inoculation of wheat with $A$. brasiliense replaced topdressing $\mathrm{N}$ fertilization only partially (Piccinin et al., 2013; Veresoglou and Menexes, 2010). For instance, Pereira et al. (2017) studied the effect of different forms of inoculation of $A$. brasilense (seed, postemergence, and sowing furrow) associated with topdressing $\mathrm{N}$ doses $(0,30$, and $60 \mathrm{~kg}$ $\mathrm{ha}^{-1}$ ) and reported that the use of half the $\mathrm{N}$ dose $\left(30 \mathrm{~kg} \mathrm{ha}^{-1}\right.$ ) associated with $A$. brasilense, regardless of the inoculation method, provided an increase in wheat yield compared to the application of half the $\mathrm{N}$ dose alone. On the other hand, the inoculation of $A$. brasilense was not able to replace the total topdressing $\mathrm{N}$ fertilization.

Vogel, Martinkoski, Jadoski and Fey (2015) found that the chemical treatment of seeds had a detrimental effect on inoculation with PGPB when it is carried out directly on the seeds. In this sense, the results observed in the present study have importance regarding the inoculation methods of PGPB, as the inoculation in post-emergence is a viable and effective alternative compared to the inoculation directly in the seeds. Fukami et al. (2016) evaluated different inoculation methods and found that the inoculant application via leaf spraying increased yield relative to the control treatments in wheat and corn crops. Pereira 
et al. (2017) reported that inoculation with $A$. brasilense in its liquid form via seed treatment, leaf application, or sowing furrow provided increases in wheat yield compared to the control treatment. On the other hand, Ferreira et al. (2017) observed increases in wheat yield when inoculated with $A$. brasilense via seed and post-emergence. However, the authors did not find significant increases when the inoculation was performed via leaf spraying.

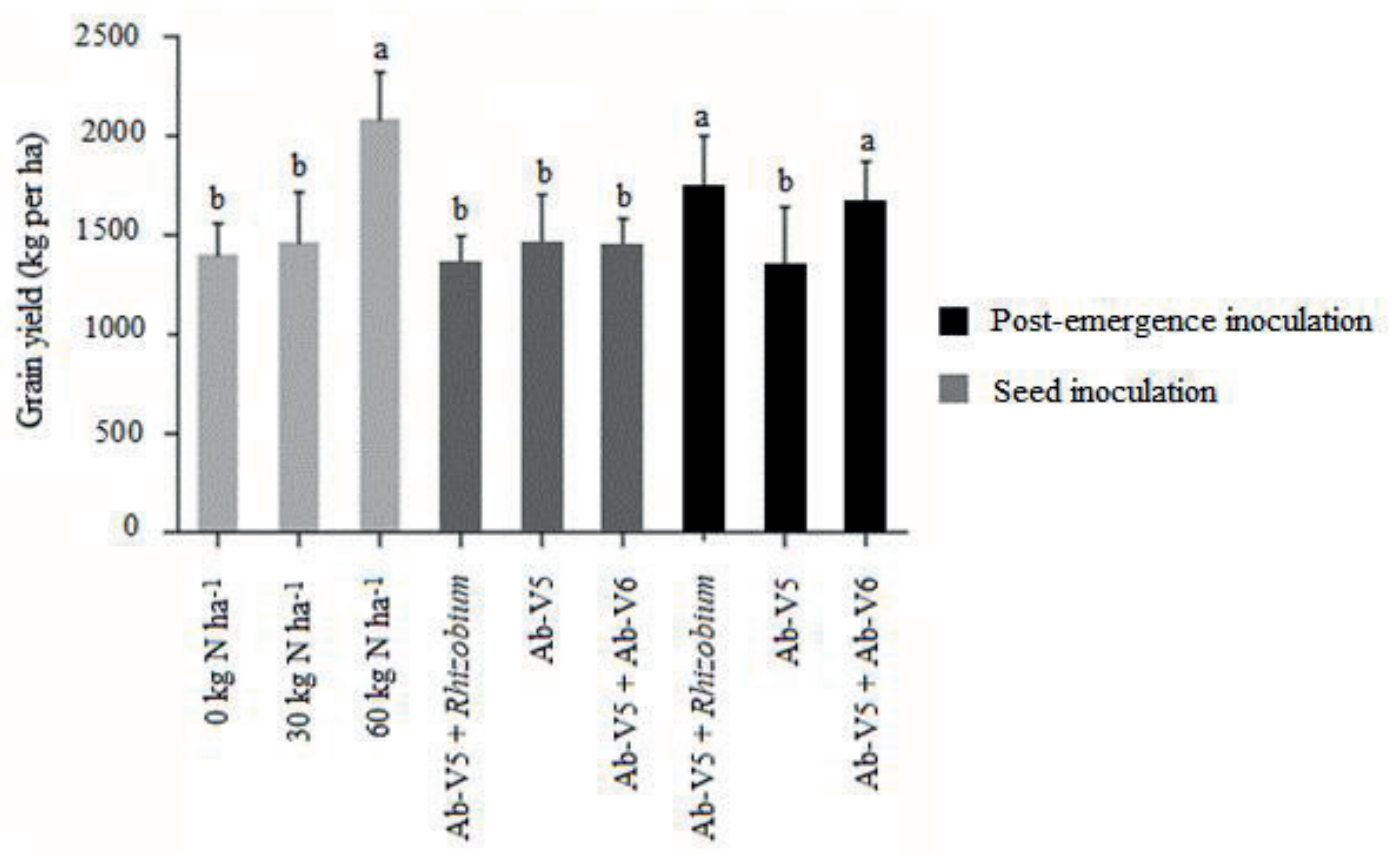

Figure 2. Means and their respective groups by the Scott and Knott (1974) test for grain yield of the wheat cultivar CD150 as a function of different inoculation methods. Means followed by the same letters constitute a statistically homogeneous group by the Scott and Knott (1974) test.

The treatment $A$. brasilense Ab-V5 + Rhizobium sp. 53GRM1 in post-emergence showed an increase of 17.42 and $15.21 \%$ in GY relative to treatments with no $\mathrm{N}$ topdressing and $30 \mathrm{~kg} \mathrm{ha}^{-1}$ of $\mathrm{N}$ topdressing, respectively (Figure 2), indicating the inoculation potential of $A$. brasilense and Rhizobium sp. in wheat cultivation. Spolaor et al. (2016) studied the effect of co-inoculation of $A$. brasilense and Rhizobium sp. in popcorn and reported an increase of $26.1 \%$ in the co-inoculated treatment relative to the non-inoculated treatment in the absence of topdressing nitrogen fertilization. Regarding the treatment commercial inoculant (A. brasilense Ab-V5 $+\mathrm{Ab}-\mathrm{V} 6)$ in post-emergence (Figure 2), the inoculation with the strains Ab-V5 + Ab-V6 showed an increase of $16.12 \%$ relative to the inoculation with only the strain Ab-V5 in postemergence. These results are corroborated by those observed by Hungria et al. (2010), who reported that the effect of strains $A b$ $\mathrm{V} 5$ and $\mathrm{Ab}-\mathrm{V} 6$ is enhanced when they are inoculated together. On the other hand, no statistical difference was observed between the treatments commercial inoculant $(A$. 
brasilense Ab-V5 + Ab-V6) and the strain AbV5 inoculated in the seeds.

Regarding LNC (Table 2), the treatments $A$. brasilense Ab-V5 in the seeds, $A$. brasilense $\mathrm{Ab}-\mathrm{V} 5+$ Rhizobium sp. 53GRM1 in the seeds, A. brasilense Ab-V5 + Rhizobium sp. 53GRM1 in post-emergence, and commercial inoculant $(A$. brasilense $\mathrm{Ab}-\mathrm{V} 5+\mathrm{Ab}-\mathrm{V} 6)$ in post-emergence presented the lowest values in Apucarana environment. However, the Londrina environment showed no significant difference between treatments. The treatment commercial inoculant (A. brasilense Ab-V5 + $\mathrm{Ab}-\mathrm{V} 6)$ in the seeds had a higher LNC mean in Apucarana than Londrina, while the treatment A. brasilense Ab-V5 in the seeds was superior in Londrina than in the Apucarana environment. Galindo et al. (2017) reported that inoculation with $A$. brasilense alone showed no effect on yield and production components of the wheat crop. However, the authors observed an increase in LNC relative to non-inoculated treatments. Hungria et al. (2010) observed a mean increase of $31 \%$ of treatments inoculated with strains Ab-V5 and Ab-V6 compared to non-inoculated treatments, which corroborates with the results obtained in the present study, in which the mean increase was $20 \%$. According to the authors, the positive effects of inoculation were attributed to general increases in the macro-and micronutrient uptake by inoculated wheat plants. Also, Camilios et al. (2014) observed changes in the expression of genes involved in the transport of nutrients of wheat plants inoculated with $A$. brasilense, directly reflecting in the uptake of nutrients such as $\mathrm{N}$.

\section{Table 2}

Leaf nitrogen content ( $\mathrm{g} \mathrm{kg}^{-1}$ ) in the wheat cultivar CD 150 as a function of different forms of fertilization in experiments conducted in Londrina and Apucarana in the 2016 agricultural year

Treatments $^{1}$

T1) Absence of $\mathrm{N}$ topdressing

T2) $30 \mathrm{~kg} \mathrm{ha}^{-1}$ of $\mathrm{N}$ topdressing

T3) $60 \mathrm{~kg} \mathrm{ha}^{-1}$ of $\mathrm{N}$ top-dressing

T4) A. brasilense Ab-V5 in the seeds

T5) $A$. brasilense $\mathrm{Ab}-\mathrm{V} 5$ in post-emergence

T6) A. brasilense Ab-V5 + Rhizobium sp. 53GRM1 in the seeds

T7) A. brasilense Ab-V5 + Rhizobium sp. 53GRM1 in post-emergence

T8) Commercial inoculant ( $A$. brasilense $\mathrm{Ab}-\mathrm{V} 5+\mathrm{Ab}-\mathrm{V} 6)$ in the seeds

T9) commercial inoculant (A. brasilense Ab-V5 + Ab-V6) in post-emergence
Site

Apucarana

Londrina

$20.03 \pm 0.96^{1} \mathrm{Aa}^{2}$

$16.97 \pm 1.22 \mathrm{Aa}$

$20.08 \pm 2.1 \mathrm{Aa}$

$19.95 \pm 1.75 \mathrm{Aa}$

$22.13 \pm 1.18 \mathrm{Aa}$

$19.07 \pm 1.92 \mathrm{Aa}$

$18.37 \pm 2.7 \mathrm{Bb}$

$24.41 \pm 3.65 \mathrm{Aa}$

$20.91 \pm 2.0 \mathrm{Aa}$

$17.41 \pm 1.57 \mathrm{Aa}$

$16.27 \pm 0.4 \mathrm{Ab}$

$17.32 \pm 0.96 \mathrm{Aa}$

$17.06 \pm 4.5 \mathrm{Ab}$

$18.37 \pm 0.98 \mathrm{Aa}$

$26.86 \pm 2.3 \mathrm{Aa}$

$17.41 \pm 1.22 \mathrm{Ba}$

$15.22 \pm 1.25 \mathrm{Ab}$

$19.16 \pm 1.13 \mathrm{Aa}$

${ }^{1}$ Means \pm standard deviation. ${ }^{2}$ Means followed by the same uppercase letters in the row (site) and lowercase letters in the columns (treatments) constitute a statistically homogeneous group using the Scott and Knott (1974) test. 
According to Cassán and Diaz-Zorita (2016), more than 104 biological products containing Azospirillum spp. are commercially available in South America alone and 64\% of them are registered for wheat cultivation. Although most of these biofertilizers are recommended for inoculation via seed, the results presented in the present study demonstrate that post-emergence inoculation can be considered an efficient strategy in coinoculation of $A$. brasilense and Rhizobium sp. in the wheat crop, bypassing the problems caused by the chemical treatment of seeds. Several other studies have reported higher efficiency of post-emergence inoculation methods, which was corroborated by the results obtained in the present study.

\section{Conclusion}

Co-inoculation with $A$. brasilense Ab$\mathrm{V} 5+$ Rhizobium sp. 53GRM1 and inoculation with $A$. brasilense Ab-V5 + Ab-V6, both in postemergence of seedlings, showed grain yield similar to the fertilization of $60 \mathrm{~kg} \mathrm{ha}^{-1}$ of $\mathrm{N}$ topdressing, indicating that these technologies have the potential to replace topdressing nitrogen fertilization in the wheat crop.

\section{References}

Arnhold, E. (2013). Package in the $R$ environment for analysis of variance and complementary analyses. Brazilian Journal of Veterinary Research and Animal Science, 50(6), 488-492. doi: 10.11606/ issn.1678-4456.v50i6p488-492

Bartlett, M. S. (1937). Properties of sufficiency and statistical tests. Proceedings of the Royal Society of London. Series A-Mathematical and Physical Sciences,
160(901), 268-282. doi: 10.1098/ rspa.1937.0109

Bremner, J. M., \& Mulvaney, C. S. (1982). Nitrogen total 1. Methods of soil analysis. Part 2. Chemical and microbiological properties (methods of soil an 2).

Camilios, D., Neto, Bonato, P., Wassem, R., TadraSfeir, M. Z., Brusamarello-Santos, L. C., Valdameri, G.,... Pedrosa, F. O. (2014). Dual RNA-seq transcriptional analysis of wheat roots colonized by Azospirillumbrasilense reveals up-regulation of nutrient acquisition and cell cycle genes. BMC Genomics, 15(1), 378. doi: 10.1186/14712164-15-378

Cassán, F., \& Diaz-Zorita, M. (2016). Azospirillum $\mathrm{sp}$. in current agriculture: from the laboratory to the field. Soil Biology and Biochemistry, 103, 117-130. doi: 10.1016/j.soilbio.2016.08.020

Castro-Sowinski, S., Herschkovitz, Y., Okon, Y., \& Jurkevitch, E. (2007). Effects of inoculation with plant growth-promoting rhizobacteria on resident rhizosphere microorganisms. FEMS Microbiology Letters, 276(1), 1-11. doi: 10.1111/j.1574-6968.2007.00878.x

Chen, J., Lü, S., Zhang, Z., Zhao, X., Li, X., Ning, P., \& Liu, M. (2018). Environmentally friendly fertilizers: a review of materials used and their effects on the environment. Science of the Total Environment, 613, 829-839. doi: 10.1016/j.scitotenv.2017.09.186

Companhia Nacional de Abastecimento (2020). Safra brasileira de grãos. Recuperado de https://www.conab. gov.br/index.php/infoagro/safras/graos

Di Salvo, L. P., Ferrando, L., FernándezScavino, A., \& Salamone, I. E. G. de. (2018). Microorganisms reveal what plants do not: wheat growth and rhizosphere microbial communities after Azospirillum brasilense inoculation and nitrogen fertilization under 
field conditions. Plant and Soil, 424(12), 405-417. doi: 10. 1007/s11104-0173548-7

Ferreira, J. P., Nunes, R. F., Silva, R. B., Dal Bem, E. A., Garcia, D. P., Sabundjian, M. T., \& Souza, F. M. L. de. (2017). Azospirillum brasilense via foliar e doses de nitrogênio em cobertura na cultura do trigo na região de Itapeva-SP/ spraying with Azospirillum on wheat leaf and nitrogen coverage rates in ItapevaSP. Revista Brasileira de Engenharia de Biossistemas, 11(2), 154-163. doi: 10.18011/bioeng2017v11n2p154-163

Fukami, J., Nogueira, M. A., Araujo, R. S., \& Hungria, M. (2016). Accessing inoculation methods of maize and wheat with Azospirillum brasilense. AMB Express, 6(1), 3. doi: 10.1186/s13568-015-0171-y

Galal Y.G.M., El-Ghandour I.A., El-Akel E.A. (2001) Stimulation of wheat growth and $\mathrm{N}$ fixation through Azospirillum and Rhizobium inoculation: A field trial with $15 \mathrm{~N}$ techniques. In: W. J .Horst (Ed.), Plant Nutrition. Developments in Plant and Soil Sciences, vol 92. Springer, Dordrecht.

Galindo, F. S., Teixeira, M. C. M., Fo., Buzetti, S., Santini, J. M. K., Alves, C. J., \& Ludkiewicz, M. G. Z. (2017). Wheat yield in the Cerrado as affected by nitrogen fertilization and inoculation with Azospirillumbrasilense. Pesquisa Agropecuária Brasileira, 52(9), 794-805. doi: 10.1590/s0100-204x20170 00900012

Galindo, F. S., Teixeira, M. C. M., Fo., Buzetti, S., Santini, J. M. K., Boleta, E. H. M., \& Rodrigues, W. L. (2020). Macronutrient accumulation in wheat crop (Triticum aestivum L.) with Azospirillum brasilense associated with nitrogen doses and sources. Journal of Plant Nutrition, 43(8), 1057-1069. doi: 10.1080/ 01904167.2020.1727511
Galindo, F. S., Teixeira, M. C. M., Fo., Tarsitano, M. A. A., Buzetti, S., Santini, J. M. K., Ludkiewicz, M. G. Z., \& Alves, C. J. (2018). Technical and economic feasibility of irrigated wheat as a function of nitrogen doses, sources, and inoculation with Azospirillum brasilense. Semina: Ciências Agrárias, 39(1), 51-66. doi: 10.5433/1679-0359.2018v39n1p51

Hoang, N. T., Tóth, K., \& Stacey, G. (2020). The role of microRNAs in the legumeRhizobium nitrogen-fixing symbiosis. Journal of Experimental Botany, 71(5), 1668-1680. doi: 10.1093/jxb/eraa018

Hungria, M., Araujo, R. S., Silva, E. B. Jr., \& Zilli, J. É. (2017). Inoculum rate effects on the soybean symbiosis in new or old fields under tropical conditions. Agronomy Journal, 109(3), 1106-1112. doi: 10.2134/ agronj 2016.11.0641

Kavimandan, S. K. (1985). Root nodule bacteria to improve yield of wheat. Plant and Soil, 86(1), 141-144. doi: 10.1007/BF02185034

Ladha, J. K., Tirol-Padre, A., Reddy, C. K., Cassman, K. G., Verma, S., Powlson, D. S.,... Pathak, H. (2016). Global nitrogen budgets in cereals: a 50-year assessment for maize, rice, and wheat production systems. Scientific Reports, 6(1), 19355. doi: 10.1038/srep19355

Lugtenberg, B., \& Kamilova, F. (2009). Plantgrowth-promoting rhizobacteria. Annual Review of Microbiology, 63(1), 541-556. doi: 10.1146/annurev.micro.62.081307.162918

Oliveira, A. L., Santos, O. J., Marcelino, P. R., Milani, K. M., Zuluaga, M. Y., Zucareli, C., \& Gonçalves, L. S. (2017). Maize inoculation with Azospirillum brasilense Ab-V5 cells enriched with exopolysaccharides and polyhydroxybutyrate results in high productivity under low $\mathrm{N}$ fertilizer input. Frontiers in Microbiology, 8, 1873. doi: 10.3389/fmicb.2017.01873 
Ohyama T. (2017) The Role of LegumeRhizobium Symbiosis in Sustainable Agriculture. In: S. Sulieman, \& L S Tran. (Eds.), Legume Nitrogen Fixation in Soils with Low Phosphorus Availability (pp.120). Springer, Cham. doi: 10.1007/978-3319-55729-8_1

Patil, A., Kale, A., Ajane, G., Sheikh, R., \& Patil, S. (2017). Plant growth-promoting Rhizobium: mechanisms and biotechnological prospective. In A. Patil, A. Kale, G. Ajane, R. Sheikh, \& S. Patil (Eds.), Rhizobium biology and biotechnology (pp. 105-134). Cham: Springer.

Pereira, L. C., Piana, S. C., Braccini, A. L., Garcia, M. M., Ferri, G. C., Felber, P. H.,... Dametto, I. B. (2017). Rendimento do trigo (Triticum aestivum) em resposta a diferentes modos de inoculação com Azospirillum brasilense. Revista de Ciências Agrárias, 4O(1), 105-113. doi: 10.19084/RCA16089

Piccinin, G. G., Braccini, A. L., Dan, L. G., Scapim, C. A., Ricci, T. T., \& Bazo, G. L. (2013). Efficiency of seed inoculation with Azospirillum brasilense on agronomic characteristics and yield of wheat. Industrial Crops and Products, 43, 393397. doi: 10.1016/j.indcrop.2012.07.052

Pii, Y., Mimmo, T., Tomasi, N., Terzano, R., Cesco, S., \& Crecchio, C. (2015). Microbial interactions in the rhizosphere: beneficial influences of plant growth-promoting rhizobacteria on nutrient acquisition process. A review. Biology and Fertility of Soils, 51(4), 403-415. doi: 10.1007/ s00374-015-0996-1

Scott, A. J., \& Knott, M. (1974). A cluster analysis method for grouping means in the analysis of variance. Biometrics, 30(3), 507-512. doi: 10.2307/2529204

Spolaor, L. T., Gonçalves, L. S. A., Santos, O. J. A. P. D., Oliveira, A. L. M. D., Scapim,
C. A., Bertagna, F. A. B., \& Kuki, M. C. (2016). Plant growth-promoting bacteria associated with nitrogen fertilization at topdressing in popcorn agronomic performance. Bragantia, 75(1), 33-40. doi: 10.1590/1678-4499.330

Silva, S. R., Bassoi, M. C., \& Foloni, J. S. S. (2017). Informações técnicas para trigo e triticalesafra 2017. Brasília: EMBRAPA Soja-Livro Técnico (INFOTECA-E). Recuperado de https://www.infoteca.cnptia.embrapa. br/infoteca/bitstream/doc/1064344/1/ TecnicasparaTrigoeTriticaleSafra2017OL. pdf

Ul-Allah, S., Iqbal, M., Maqsood, S., Naeem, M., ljaz, M., Ashfaq, W., \& Hussain, M. (2018). Improving the performance of bread wheat genotypes by managing irrigation and nitrogen under semi-arid conditions. Archives of Agronomy and Soil Science, 64(12), 1678-1689. doi: 10.1080/03650340.2018.1450974

Vaghar, M., \& Ehsanzadeh, P. (2018). Comparative photosynthetic attributes of emmer and modern wheats in response to water and nitrogen supply. Photosynthetica, 56(4), 1224-1234. doi: 10.1007/s11099-018-0825-5

Veresoglou, S. D., \& Menexes, G. (2010). Impact of inoculation with Azospirillum spp. on growth properties and seed yield of wheat: a meta-analysis of studies in the ISI Web of Science from 1981 to 2008. Plant and Soil, 337(1-2), 469-480. doi: 10.1007/ s11104-010-0543-7

Vogel, G. F., Martinkoski, L., Jadoski, S. O., \& Fey, R. (2015). Efeitos na combinação de Azospirillum brasilense com fungicidas no desenvolvimento de trigo. Brazilian Journal of Applied Technology for Agricultural Science/Revista Brasileira de Tecnologia Aplicada nas Ciências Agrárias, 8(2), 7380. doi: 10.5935/PAeT.V8.N3.08 
Yang, C., Hamel, C., Vujanovic, V., \& Gan, Y. (2011). Fungicide: modes of action and possible impact on nontarget microorganisms. ISRN Ecology, 2011, 1-8. doi: 10.5402/2011/130289

Yanni, Y. G., Dazzo, F. B., Squartini, A., Zanardo, M., Zidan, M. I., \& Elsadany, A. E. Y. (2016). Assessment of the natural endophytic association between Rhizobium and wheat and its ability to increase wheat production in the Nile delta. Plant and Soil, 407(1-2), 367-383. doi: 10.1007/s11104016-2895-0

Zeffa, D. M., Fantin, L. H., Koltun, A., Oliveira, A. L. de, Nunes, M. P., Canteri, M. G., \& Gonçalves, L. S. (2020). Effects of plant growth-promoting rhizobacteria on co-inoculation with Bradyrhizobium in soybean crop: a meta-analysis of studies from 1987 to 2018. PeerJ, 8, e7905. doi: 10.7717/peerj.7905
Zeffa, D. M., Fantin, L. H., Santos, O. J. A. P. D., Oliveira, A. L. M. D., Canteri, M. G., Scapim, C. A., \& Gonçalves, L. S. A. (2018). The influence of topdressing nitrogen on Azospirillum spp. inoculation in maize crops through meta-analysis. Bragantia, 77(3), 493-500. doi: 10.1590/16784499.2017273

Zeffa, D. M., Perini, L. J., Silva, M. B., Sousa, N. V. de, Scapim, C. A., Oliveira, A. L. M. de,... Goncalves, L. S. A. (2019). Azospirillum brasilense promotes increases in growth and nitrogen use efficiency of maize genotypes. PloS One, 14(4), e0215332. doi: 10.1371/journal.pone.0215332 
